\title{
Skeletal effects of RME in the transverse and vertical dimensions of the nasal cavity in mouth-breathing growing children
}

\author{
Mario Cappellette Jr. ${ }^{1}$, Lucia Hatsue Yamamoto Nagai², Raquel Mori Gonçalves², \\ Aparecida Keiko Yuki², Shirley Shizue Nagata Pignatari, Reginaldo Raimundo Fujita ${ }^{1}$
}

DOI: https://doi.org/10.1590/2177-6709.22.4.061-069.oar

\begin{abstract}
Introduction: Maxillary constriction is a dentoskeletal deformity characterized by discrepancy in maxilla/mandible relationship in the transverse plane, which may be associated with respiratory dysfunction. Objective: The objective of this study was to evaluate the skeletal effects of RME on maxillary and nasal transverse dimensions and compare the differences between males and females. Methods: Sixty-one mouthbreathers patients with skeletal maxillary constriction ( 35 males and 26 females, mean age 9.6 years) were included in the study. Posteroanterior (PA) radiographs were taken before expansion $\left(\mathrm{T}_{1}\right)$ and 3 months after expansion $\left(\mathrm{T}_{2}\right)$. Data obtained from the evaluation of $\mathrm{T}_{1}$ and $\mathrm{T}_{2}$ cephalograms were tested for normality with the Kolmogorov-Smirnov method. The Student's $t$-test was performed for each measurement to determine sex differences. Results: RME produced a significant increase in all linear measurements of maxillary and nasal transverse dimensions. Conclusions: No significant differences were associated regarding sex. The RME produced significant width increases in the maxilla and nasal cavity, which are important for treatment stability, improving respiratory function and craniofacial development.
\end{abstract}

Keywords: Palatal expansion technique. Maxilla. Mouth-breathing.

Introdução: a constrição maxilar é uma alteração dentoesquelética relacionada à diminuição transversal da arcada superior, que pode correlacionar-se com problemas respiratórios. O tratamento nos pacientes em crescimento inclui a expansão rápida da maxila (ERM). A correção precoce resulta em maiores alterações esqueléticas e estabilidade dos resultados, podendo evitar desvios de crescimento facial. Objetivo: avaliar comparativamente, por meio de telerradiografias posteroanteriores (PA), as alterações dimensionais da cavidade nasal pré- e pós-ERM em pacientes respiradores bucais dos sexos masculino e feminino. Métodos: realizou-se o estudo de medidas lineares em telerradiografias PA pré- e pós-ERM de uma amostra composta por 61 pacientes ( 35 do sexo masculino e 26 do feminino), com média de idade de 9,6 anos. Todos os pacientes eram respiradores bucais com constrição maxilar esquelética, e foram tomadas radiografias PA pré- e pós-ERM (3 meses). Os dados obtidos foram avaliados nos tempos $T_{1} \mathrm{e}$ $\mathrm{T}_{2}$ a normalidade dos dados foi confirmada por meio do teste de Kolmogorov-Smirnov. O teste $t$ de Student foi aplicado para cada mensuração, para determinar diferenças entre os sexos. Resultados: a ERM promoveu aumento significativo em todas as medidas lineares maxilares e das dimensões da cavidade nasal. Conclusão: nenhuma diferença significativa foi associada ao sexo. A ERM produziu aumentos significativos na largura maxilar e volume da cavidade nasal, que são importantes na estabilidade do tratamento Nos pacientes em crescimento e respiradores bucais com constrição maxilar esquelética da maxila, a ERM promoveu aumento do volume da cavidade nasal que melhorou o fluxo aéreo e possibilitou reconduzir o crescimento facial. As alterações transversais não foram significativas quando relacionadas ao sexo.

Palavras-chave: Técnica de expansão palatal. Maxila. Respirador bucal.

${ }^{1}$ Universidade Federal de São Paulo, Departamento de Otorrinolaringologia e Cirurgia de Cabeça e Pescoço (São Paulo/SP, Brasil).

${ }^{3}$ Private practice (São Paulo/SP, Brasil).

" The authors report no commercial, proprietary or financial interest in the products or companies described in this article. Patients displayed in this article previously approved the use of their facial and intraoral photographs.

Submitted: July 27, 2016 - Revised and accepted: February 03, 2017
How to cite: Cappellette Jr. M, Nagai LHY, Gonçalves RM, Yuki AK, Pignatari SSN, Fujita RR. Skeletal effects of RME in the transverse and vertical dimensions of the nasal cavity in mouth-breathing growing children. Dental Press J Orthod. 2017 July-Aug;22(4):61-9.

DOI: https://doi.org/10.1590/2177-6709.22.4.061-069.oar

Contact address: Mario Cappellette Jr.

Rua Salete, 200, conj. 101/102 - CEP: 02.016-001, São Paulo/SP, Brasil E-mail: mjrcappellette@terra.com.br 


\section{INTRODUCTION}

Maxillary constriction is a narrowing of the upper arch and is one of the most prevalent malocclusions. Some of its typical features are unilateral or bilateral posterior crossbite, anterior dental crowding, a high palatal vault, and a decrease in the distance between the lateral walls of the nasal cavity. ${ }^{1}$ The etiology is believed to be multifactorial $^{2}$ and the main factors includes physiological problems, genetic and parafunctional habits ${ }^{3}$ that could lead to a mixed or mouth-breathing pattern. ${ }^{4,5}$ Since the airway is assumed to play a role in dentofacial development, the association with respiratory problems, especially nasal obstruction, has been the focus of many researchers who have investigated the possibility that these events are related. ${ }^{6}$ However, it could be considered erroneous to associate malocclusions only with the breathing pattern. ${ }^{2}$

The maxillary bones form approximately $50 \%$ of the nasal cavity's anatomic structure. ${ }^{7} \mathrm{RME}$ is a dentofacial orthopedic treatment procedure that has been widely used for correcting maxillary transverse deficiency in young patients and it can change the morphology of the maxillary arch, affecting the geometry and function of the nasal cavity. ${ }^{7}$ Eysel, in 1886, cited by Haas ${ }^{8,9}$ was the first rhinologist who studied the effect of RME on nasal cavity function. He found that, in the post-RME period, various changes occurred in the maxilla and adjacent bones, and RME caused an opening of the nasal cavity and reduction in nasal airway resistance. In addition, after the expansion an increase was found in the nasal cavity width and in the nasal base adjacent to the midpalatal suture. The maxillary sutures separate the external walls of the nasal cavity laterally, resulting in an increase in the intranasal capacity. Although orthodontic treatment is carried out to correct dental and skeletal discrepancies, some authors showed that RME outcomes could also be effective on naso-respiratory and sleep-disordered breathing problems of growing children. ${ }^{11}$ Therefore, RME has been suggested in the medical treatment of mouth-breathing, septal deformity, nasal infection, allergic rhinitis, and obstructive sleep apnea. However, its clinical use for rhinological effects is controversial. ${ }^{12}$ Its primary goal is to maximize orthopedic and minimize orthodontic tooth movement ${ }^{13}$ and there is an agreement among orthodontists that a maxillary constriction should be treated early, ${ }^{9}$ since the proportion of skeletal and dental movement depends on patient's age and ma- turity level. ${ }^{14,15}$ In a study of RME effects, sex differences proved to be important as it is known that the facial skeleton significantly increases its resistance to expansion with increasing age and maturity. ${ }^{15}$

The majority of growth studies have used lateral cephalometric radiographs to analyze vertical and sagittal dimensional changes of the face. However, transverse problems and development of the oronasal area can be better understood by analyzing posteroanterior (PA) cephalometric radiographs. ${ }^{5}$ Structural remodeling of nasal cavity has the effect of increasing nasal patency after RME, and the relevance of PA radiograph is to show this remodeling and quantify the increase in nasal cavity, ${ }^{16}$ especially in the midface, since its walls are laterally displaced. The purpose of this article was to evaluate the skeletal effects of RME in the transverse and vertical dimensions on nasal cavity in mouth-breathing growing children and to correlate it with both sexes.

\section{MATERIAL AND METHODS}

The study sample comprised 61 children (mean age 9.6 years, range $6.5-13.10$ years; 35 male, 26 female) regardless of facial type or race, who sought treatment at the Department of Pediatric Otorhinolaryngology of the Universidade Federal de São Paulo, in Brazil. The criteria for selection of the treatment group were as follows: skeletal constricted maxillary arches, unilateral or bilateral posterior crossbite requiring RME treatment, and mouth-breathing. The exclusion criteria were: no maxillary first molars, metallic restorations, periodontal diseases, previous orthodontic treatment, and genetic disease involving chromosome or mutations.

In order to check for the mouth-breathing pattern, all patients were clinically examined by an experienced otorhinolaryngologist that verified the presence of nasal obstruction after anterior rhinoscopy, oroscopy and nasofiberendoscopy ${ }^{17}$. Potential candidates for adenoidectomy or adenotonsillectomy, with complete occlusion of the nasal cavity by nasal turbinates, intranasal tumors or polyps, adenoid occupying more than $70 \%$ of the choanas were excluded from the study.

The subjects were divided into two groups: males (mean age 10.1 years, range 6.5-13.10 years) and females (mean age 9.2 years, range $6.5-12.5$ years). The study was approved by the Research Ethics Committee of Universidade Federal de São Paulo (protocol \#0907/08) and an informed consent was obtained from the parents or guardians, besides the verbal assent from the children before data collection for the study. 


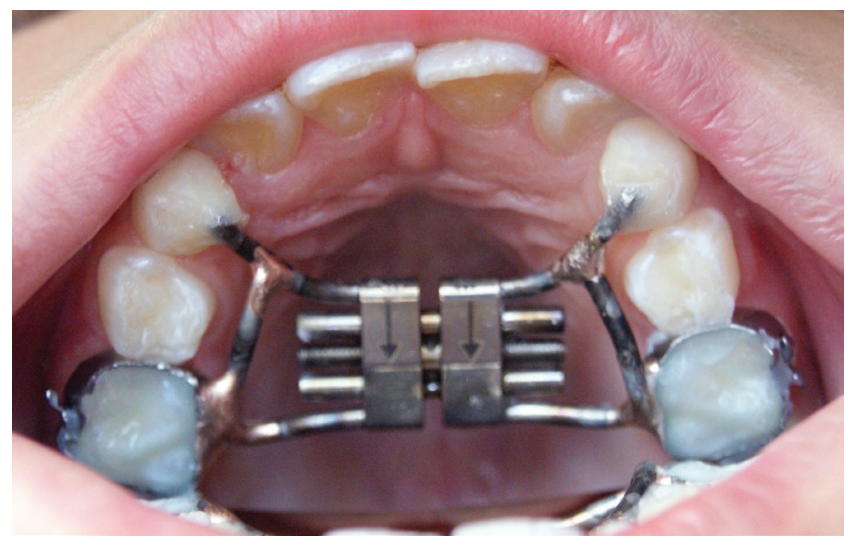

Figure 1 - RME appliance, comprising a tooth-anchored device (conventional Hyrax expander).

The orthodontic phase of treatment was undertaken at a local orthodontic clinics under the supervision of the department's orthodontists.

Pretreatment $\left(\mathrm{T}_{1}\right)$ orthodontic records, including PA radiographs were taken for all patients. Each patient underwent a standardized RME protocol using a tooth-anchored device activated by means of a modified Hyrax expander with a soldered framework and orthodontic bands on deciduous second molars and extended forward to the palatal surfaces of the deciduous canines (Fig 1); or supported by bilateral maxillary first premolars and first molars, in case the first premolars were sufficiently erupted. After the expander was cemented, it was activated six turns. Then, the parents or guardians were instructed to activate the jackscrew one turn $(0.25 \mathrm{~mm})$ twice a day until the required expansion was achieved. The degree of expansion was calculated for each patient, including a bilateral overexpansion and buccal tipping of a half-cusp width. After a mean active expansion period of 15 days (range 7- 21 days), the expander was tied off with a ligature wire and it was kept on the teeth as a passive retainer for at least 90 days (3 months), ranging from 91 to 106 days. This retention period allowed osseous reorganization of the midpalatal suture after expansion. All patients did not receive brackets or wires on the maxillary arch until $\mathrm{T}_{2}$ records were taken.

Postexpansion $\left(T_{2}\right)$ PA cephalograms were taken after removal of the expander. The mean interval between $\mathrm{T}_{1}$ and $\mathrm{T}_{2}$ was 98 days (range, 91-105 days). As a result, study sample was composed by 122 PA cephalograms, which were hand traced with a $0.5-\mathrm{mm}$ lead pencil on Ultraphan acetate tracing paper. All tracings were performed by the same investigator.

Tables 1 and 2 show the skeletal and dental landmarks, and linear measurements (in millimeters) from Ricketts' cephalometric analysis. ${ }^{17}$

\section{Statistics analysis}

Descriptive statistics including mean, standard deviation (SD), and ranges were calculated for $\mathrm{T}_{1}$ and $\mathrm{T}_{2}$ measurements. Independent samples $t$-test was performed for each measurement, to determine sex differences. Significance for all statistical tests was predetermined at $p<0.05 . \mathrm{T}_{1}$ and $\mathrm{T}_{2}$ measurements and comparisons are presented in Tables 3 to 6 . To estimate intraexaminer error, reliability and reproducibility, 20 randomly selected records (10 males and 10 females) were reevalu-
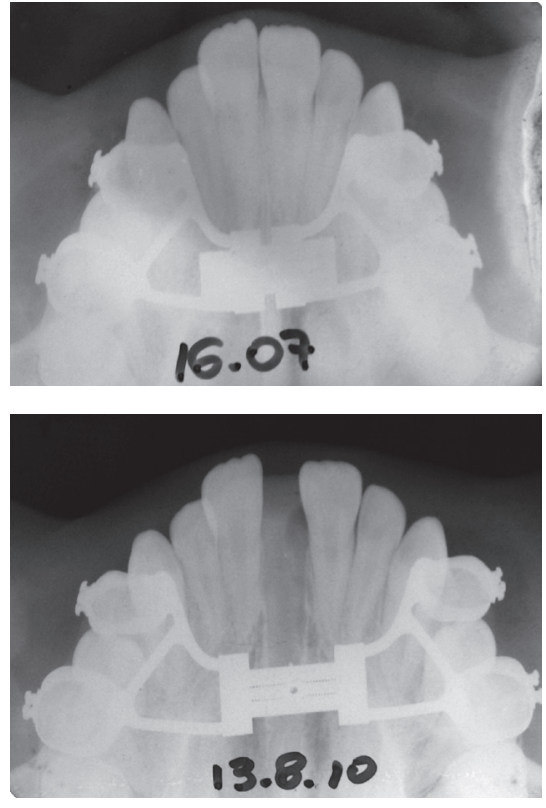
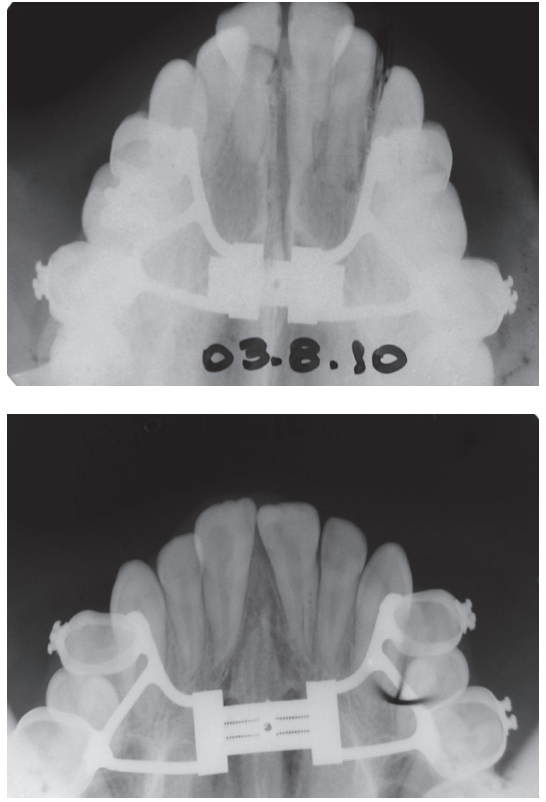

Figure 2 - Pre-RME and post-RME occlusal radiographs. 


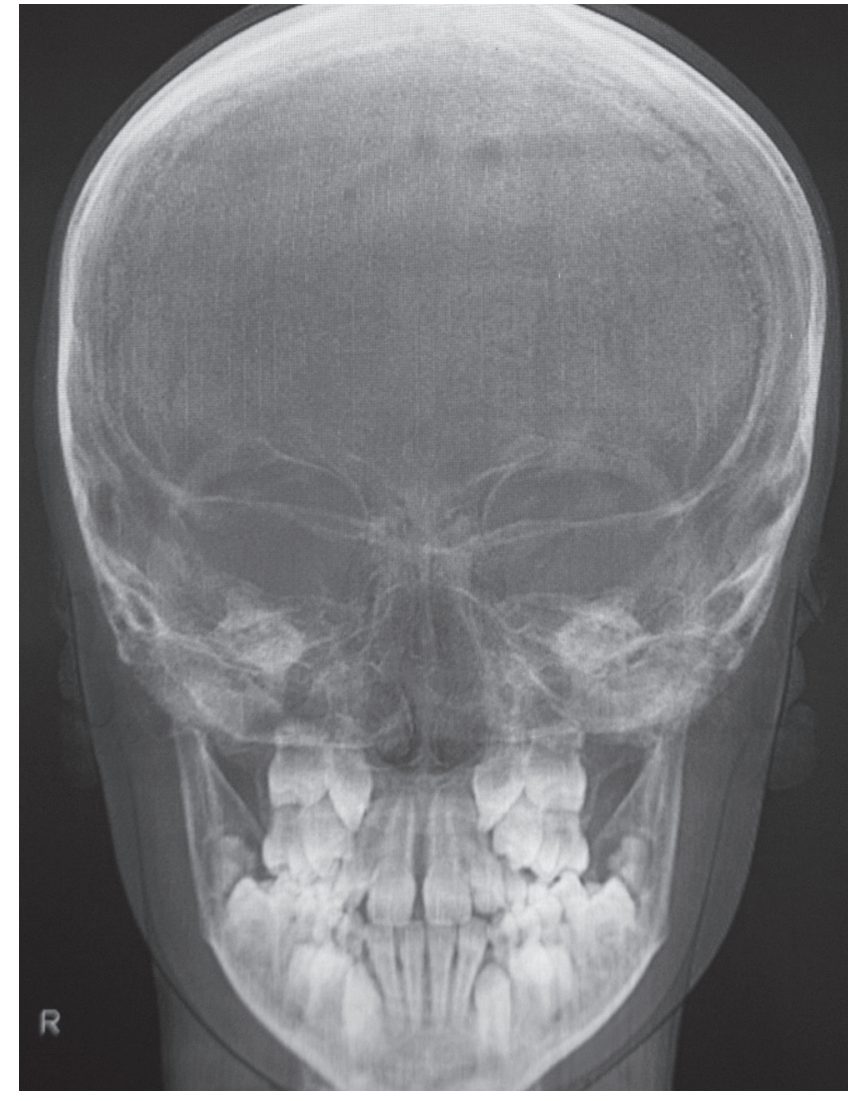

Figure 3 - PA cephalometric radiograph pre-RME.

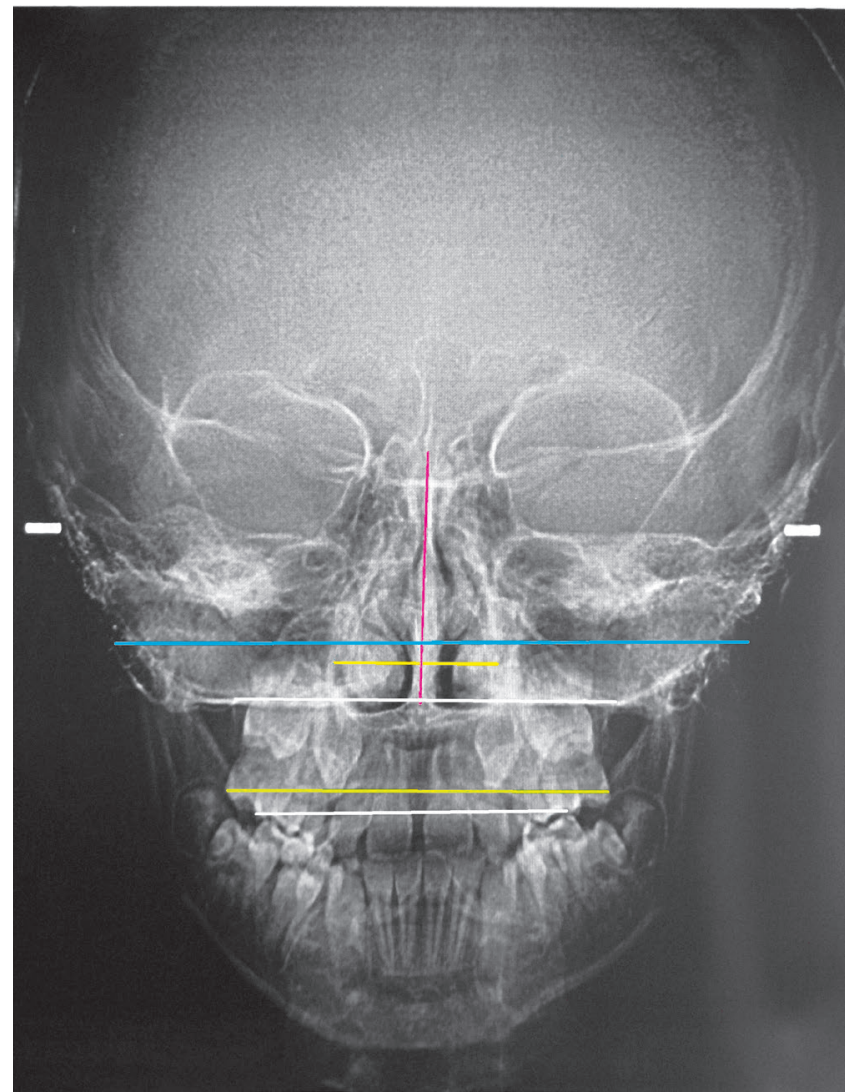

Figure 4 - PA cephalometric radiograph post-RME, showing lines used for measurements.

Table 1 - Posteroanterior skeletal and dental landmarks.

\begin{tabular}{ll}
\hline Landmark & Description \\
NC/CN & The most lateral point of the nasal cavity \\
\hline ZL/ZR & The most internal point of the frontozygomatic \\
ANS & Anterior nasal spine \\
JL/JR & Deepest point of the alveolar maxillary process \\
UML/UMR & The most prominent lateral point on the buccal surface of permanent first molar crown \\
\hline
\end{tabular}

Table 2 - Posteroanterior planes and linear measurements.

\begin{tabular}{ll}
\hline Reference plane and line & Reference Plane Description \\
\hline ZL-ZR & Z plane- reference line in the horizontal plane \\
\hline Occlusal plane & Occlusal line in the molars \\
\hline NC-CN & Nasal width \\
\hline ANS-Z plane $(\mathrm{NH})$ & Nasal height \\
\hline JL-JR & Maxillary width \\
\hline IM & Intermolar width - distance between UML-UMR parallel to the occlusal plane. \\
\hline IM/ JL-JR & Ratio between intermolar width and maxillary width \\
\hline JL-JR/ NC-CN & Ratio between maxillary width and nasal width \\
\hline
\end{tabular}


Table 3 - Comparisons of T1 values between males and females.

\begin{tabular}{|c|c|c|c|c|c|}
\hline Variable & Sex & Mean & n & SD & $\mathbf{P}$ \\
\hline \multirow{2}{*}{ Age (month) } & Males & 121.5 & 35 & 24.8 & \multirow{2}{*}{0.070} \\
\hline & Females & 108.2 & 26 & 31.5 & \\
\hline \multirow{2}{*}{ Height (mm) } & Males & 53.9 & 35 & 3.4 & \multirow{2}{*}{$0.025^{\star}$} \\
\hline & Females & 51.6 & 26 & 4.3 & \\
\hline \multirow{2}{*}{ Nasal width (mm) } & Males & 28.7 & 35 & 2.8 & \multirow{2}{*}{0.782} \\
\hline & Females & 28.5 & 26 & 3.2 & \\
\hline \multirow{2}{*}{$\begin{array}{c}\text { Área (nasal width } x \text { nasal } \\
\text { height) }\left(\mathrm{mm}^{2}\right)\end{array}$} & Males & 1551.8 & 35 & 206.5 & \multirow{2}{*}{0.153} \\
\hline & Females & 1473.1 & 26 & 214.5 & \\
\hline \multirow{2}{*}{ Maxillary width (mm) } & Males & 63.6 & 35 & 3.8 & \multirow{2}{*}{0.026} \\
\hline & Females & 61.4 & 26 & 3.6 & \\
\hline \multirow{2}{*}{ Intermolar width ( $\mathrm{mm}$ ) } & Males & 58.3 & 35 & 3.6 & \multirow{2}{*}{0.239} \\
\hline & Females & 57.2 & 26 & 3.7 & \\
\hline \multirow{2}{*}{$\begin{array}{l}\text { Intermolar width/ Maxillary } \\
\text { width ratio }\end{array}$} & Males & 1.09 & 35 & 0.06 & \multirow{2}{*}{0.426} \\
\hline & Females & 1.08 & 26 & 0.08 & \\
\hline \multirow{2}{*}{ Maxillary width / Nasal width } & Males & 2.23 & 35 & 0.19 & \multirow{2}{*}{0.267} \\
\hline & Females & 2.17 & 26 & 0.20 & \\
\hline
\end{tabular}

NS = nonsignificant; $n=$ number of patients; SD = standard deviation. *Statistically significant $(p<0.05)$.

Table 4 - Comparisons of $T_{2}$ measurements between males and females.

\begin{tabular}{|c|c|c|c|c|c|}
\hline Variable & Sex & Mean & $n$ & SD & $\mathbf{P}$ \\
\hline \multirow{2}{*}{ Height (mm) } & Males & 56.4 & 35 & 3.65 & \multirow{2}{*}{$0.05^{\star}$} \\
\hline & Females & 54.2 & 26 & 4.79 & \\
\hline \multirow{2}{*}{ Nasal width (mm) } & Males & 31.3 & 35 & 3.27 & \multirow{2}{*}{0.543} \\
\hline & Females & 31.9 & 26 & 3.61 & \\
\hline \multirow{2}{*}{$\begin{array}{c}\text { Área (nasal width } \times \text { nasal } \\
\text { height) }\left(\mathrm{mm}^{2}\right)\end{array}$} & Males & 1770.7 & 35 & 248.6 & \multirow{2}{*}{0.548} \\
\hline & Females & 1730.8 & 26 & 263.1 & \\
\hline \multirow{2}{*}{ Maxillary width (mm) } & Males & 67.4 & 35 & 3.32 & \multirow{2}{*}{$0.007^{* *}$} \\
\hline & Females & 64.7 & 26 & 4.05 & \\
\hline \multirow{2}{*}{ Intermolar width (mm) } & Males & 65.4 & 35 & 3.44 & \multirow{2}{*}{$0.029 *$} \\
\hline & Females & 62.9 & 26 & 5.08 & \\
\hline \multirow{2}{*}{$\begin{array}{l}\text { Intermolar width/ } \\
\text { Maxillary width ratio }\end{array}$} & Males & 1.03 & 35 & 0.04 & \multirow{2}{*}{0.996} \\
\hline & Females & 1.03 & 26 & 0.07 & \\
\hline \multirow{2}{*}{$\begin{array}{l}\text { Maxillary width / Nasal } \\
\text { width }\end{array}$} & Males & 2.17 & 35 & 0.18 & \multirow{2}{*}{$0.014^{*}$} \\
\hline & Females & 2.05 & 26 & 0.18 & \\
\hline
\end{tabular}

NS = nonsignificant; $\mathrm{n}=$ number of patients; $\mathrm{SD}=$ standard deviation. Statistically significant, ${ }^{*} p<0.05,{ }^{* *} p<0.01$. 
Table 5 - Comparisons of changes from $T_{1}$ to $T_{2}$, between males and females.

\begin{tabular}{|c|c|c|c|c|c|}
\hline Variable & Sex & Mean & $n$ & SD & $\mathbf{P}$ \\
\hline \multirow{2}{*}{ Differences in height (mm) } & Males & 2.4 & 35 & 1.45 & \multirow{2}{*}{0.750} \\
\hline & Females & 2.6 & 26 & 1.82 & \\
\hline \multirow{2}{*}{$\begin{array}{l}\text { Differences in nasal width } \\
\qquad(\mathrm{mm})\end{array}$} & Males & 2.6 & 35 & 1.40 & \multirow{2}{*}{$0.027^{*}$} \\
\hline & Females & 3.4 & 26 & 1.20 & \\
\hline \multirow{2}{*}{$\begin{array}{l}\text { Differences in area (nasal } \\
\text { width x nasal height) }\left(\mathrm{mm}^{2}\right)\end{array}$} & Males & 218.8 & 35 & 93.9 & \multirow{2}{*}{0.103} \\
\hline & Females & 257.7 & 26 & 86.0 & \\
\hline \multirow{2}{*}{$\begin{array}{l}\text { Differences in maxillary } \\
\text { width (mm) }\end{array}$} & Males & 3.8 & 35 & 3.11 & \multirow{2}{*}{0.550} \\
\hline & Females & 3.3 & 26 & 2.12 & \\
\hline \multirow{2}{*}{$\begin{array}{l}\text { Differences in intermolar } \\
\text { width }(\mathrm{mm})\end{array}$} & Males & 7.1 & 35 & 3.15 & \multirow{2}{*}{0.124} \\
\hline & Females & 5.8 & 26 & 3.41 & \\
\hline \multirow{2}{*}{$\begin{array}{l}\text { Differences in intermolar } \\
\text { width/Maxillary width ratio }\end{array}$} & Males & -0.06 & 35 & 0.06 & \multirow{2}{*}{0.237} \\
\hline & Females & -0.04 & 26 & 0.05 & \\
\hline \multirow{2}{*}{$\begin{array}{l}\text { Differences in maxillary } \\
\text { width/Nasal width }\end{array}$} & Males & -0.06 & 35 & 0.10 & \multirow{2}{*}{$0.019 *$} \\
\hline & Females & -0.12 & 26 & 0.10 & \\
\hline
\end{tabular}

NS = nonsignificant; $\mathrm{n}=$ number of patients; SD = standard deviation. ${ }^{*}$ Statistically significant $(p<0.05)$.

Table 6 - Changes from $T_{1}$ to $T_{2}$ within the groups of males and females.

\begin{tabular}{|c|c|c|c|c|}
\hline Variable & Mean & $\mathbf{N}$ & SD & P \\
\hline Differences in height (mm) & 2.5 & 61 & 1.6 & $0.000 * *$ \\
\hline Differences in nasal width (mm) & 2.9 & 61 & 1.4 & $0.000^{* *}$ \\
\hline Differences in area (nasal width $x$ nasal height) $\left(\mathrm{mm}^{2}\right)$ & 235.4 & 61 & 91.9 & $0.000 * *$ \\
\hline Differences in maxillary width (mm) & 3.6 & 61 & 2.7 & $0.000 * *$ \\
\hline Differences in intermolar width (mm) & 6.5 & 61 & 3.3 & $0.000 * *$ \\
\hline Differences in intermolar width/Maxillary width ratio & -0.05 & 61 & 0.06 & $0.000 * *$ \\
\hline Differences in maxillary width/Nasal width & -0.09 & 61 & 0.10 & $0.000 * *$ \\
\hline
\end{tabular}

$\mathrm{n}=$ number of patients; SD $=$ standard deviation. ${ }^{*}$ Statistically significant $(p<0.01)$.

ated after approximately 6 months from preliminary data collection. All parameters were measured by the same observer (intraexaminer error). Normality was assessed with the Shapiro-Wilk test $(p>0.05)$. After that, Student's $t$-tests were used to investigate the difference between both measurements, and intraclass correlation coefficient (ICC) was used to test reliability. Statistical treatment of the data was performed using Statistical Package for the Social Sciences (SPSS), version 22 for Windows. All statistical analyses were performed using SPSS v. 16.0 (SPSS Inc, IL, USA) software.

\section{Normality of data}

The normality of data was assessed by the ShapiroWilk test. Considering a significance level of $5 \%$, there were no significant deviations from the normality of the data $(p>0.05)$, neither in $T_{1}$ nor in $T_{2}$. For this reason, the following parametric tests were used to analyze the error and reliability of the measurements: Student's $t$-test for paired samples and Intraclass Correlation Coefficient (ICC).

\section{Sample calculation}

In this study, the effect size of Student's $t$-tests was calculated to verify the suitability of the sample for independent samples (comparisons for the sexes) and paired samples (comparison between $T_{1}$ and $T_{2}$ ), with a power of $80 \%$ and a significance level of 5\%. The classifications for effect size proposed by Cohen ${ }^{19}$ were considered: $\mathrm{D}=0.2$, small effect; $\mathrm{D}=0.5$, mean effect; $\mathrm{D}=0.8$, high effect. The calculations were performed with the $G \star$ Power software. $^{20}$ 
Under these conditions, the sample allowed to detect mean effects (Cohen's D $=0.65$ ) in the comparison between the male group $(n=35)$ and the female group $(\mathrm{n}=26)$. For the comparison between $\mathrm{T}_{1}$ and $\mathrm{T}_{2}(\mathrm{n}=61)$, the sample allowed to detect small effects (Cohen $\mathrm{D}=0.32$ ).

\section{Method error analysis}

The results obtained through the Student's $t$-test for paired samples showed correspondence between the initial measurements and the repetitions by the same evaluator (Intraclass Correlation Coefficient), both in $\mathrm{T}_{1}\left(p>0.05\right.$ and ICC close to 1.000) and in $\mathrm{T}_{2}(p>0.05$ and ICC close to 1.000), indicating the absence of measurement error, reliability and reproducibility (Table 7).

\section{RESULTS}

Table 3 refers to sex differences in $\mathrm{T}_{1}$ and it shows statistical significance for nasal height and maxillary width variables, which were smaller in female group.

Table 4 compares the sex differences at $\mathrm{T}_{2}$. RME produced greater increases in the male group for nasal height, maxillary width, intermolar width and nasal width/maxillary width ratio.

Table 5 compares the sex differences at $\mathrm{T}_{1}$ and $\mathrm{T}_{2}$. Significant changes in the nasal width were observed in female group, and the nasal width/maxillary width ratio was smaller in female group.

Table 6 shows changes within the groups $\left(\mathrm{T}_{2}-\mathrm{T}_{1}\right)$. RME produced skeletal, dental and nasal increases in both males and females.

All measurements were considered to be reliable, since the reliability statistics were equal to 1 , which indicates perfect reliability.

\section{DISCUSSION}

In both males and females groups, the maxilla showed a significant increase for the linear measurements after RME, which is in accordance to the findings of other authors that reported post-RME sagittal and transverse increases of skeletal, dental and nasal structures. ${ }^{3,15,21-23}$ According to Wriedt et $\mathrm{al}^{24}$ and Warren et $\mathrm{al},{ }^{25}$ the enlargement of the nasal valve with an increase of nasal volume can result in improvement of nasal breathing. More controversial is the question of whether RME can achieve a shift from mouth to nasal breathing patterns and change the subjective sensation of nasal obstruction. ${ }^{26}$ These effects depend on the existence or not of nasal obstruction and on its cause, location and severity. ${ }^{6}$

Statistical results in Table 3, which compares the values obtained in the pre-RME $\left(\mathrm{T}_{1}\right)$ between males and females, show that most of the variables were not significant $(p>0.05)$ indicating no correlation between sex and the linear measurements in $T_{1}$. The two statistically significant variables - nasal height $(p=0.025)$ and maxillary width $(p=0.026)$ for males are in agreement with other studies in the literature ${ }^{5}$. Snodell et $\mathrm{al}^{5}$ showed sex differences in maxillary width at 6 years old and higher values for maxillary width and intermolar width at age 12 years in males. In the composition of the mean values of the nasal cavity found by Ricketts et al, ${ }^{18}$ the proportion between nasal height and nasal width represents $60 \%$. In this study, this proportion was $56 \%$ in both males and females groups, confirming reduced nasal width in the mouth-breathing sample. Whereas the growth in the vertical direction is larger than in the transverse one, from 6 to 18 years of age - with a

Table 7 - Error analysis: mean and standard deviation (SD), Student's $t$-test for paired samples and ICC $(n=20)$.

\begin{tabular}{|c|c|c|c|c|c|}
\hline Variable & $\operatorname{Sex}$ & $\begin{array}{c}\text { Measurement } T_{1} \\
\text { Mean (SD) }\end{array}$ & $\begin{array}{c}\text { Measurement } \mathrm{T}_{2} \\
\text { Mean (SD) }\end{array}$ & Student's t-test & ICC \\
\hline \multirow{2}{*}{ Nasal width } & Males & $21.78(1.64)$ & $23.74(2.68)$ & 0.531 & 0.989 \\
\hline & Females & $22.22(1.71)$ & $22.12(1.56)$ & 0.671 & 0.907 \\
\hline \multirow{2}{*}{ Height } & Males & $42.77(3,99)$ & $45.94(4.29)$ & 0.477 & 0.999 \\
\hline & Females & $41.0(4.09)$ & $40.83(4.01)$ & 0.267 & 0.993 \\
\hline \multirow{2}{*}{ Intermolar width } & Males & $102.55(5.41)$ & $104.16(5.19)$ & 0.443 & 0.999 \\
\hline & Females & $101.21(4.19)$ & $101.3(4.42)$ & 0.653 & 0.991 \\
\hline \multirow{2}{*}{ Maxillary width } & Males & $58.72(2,86)$ & $61.93(3.42)$ & 0.067 & 0.998 \\
\hline & Females & $58.79(3.03)$ & $58.71(3.01)$ & 0.070 & 0.998 \\
\hline
\end{tabular}

$\mathrm{SD}=$ standard deviation. ${ }^{*}$ Statistically significant $(p<0.05)$ 
increased percent in males - and by evaluating the mean age of the sample, the proportion between the values of transverse and vertical measures was below the one found in longitudinal studies of facial growth. ${ }^{5}$ These results are consistent with studies reporting a decrease in measures of the nasal cavity in mouth-breathing patients. ${ }^{6}$

The results in Table 4 refer to the sex difference at $T_{2}$. RME produced greater increases in the male group for nasal height $(p=0.05)$, maxillary width $(p=0.026)$, intermolar width $(p=0.029)$ and nasal width/maxillary width ratio $(p=0.014)$. The maxillary width increase correlates with intermolar width, according to longitudinal cephalometric studies, and the nasal width was also correlated with maxillary width and maxillary intermolar width. ${ }^{5}$ The greatest increase in the maxillary width and in the intermolar width in males can be understood by the higher bone resistance of females, which complete puberty earlier than males, and the higher maxillary growth rate in males, which may affect resistance to the expansion forces,${ }^{27}$ leading to increased expression of dental effects in males. For this reason, timing orthodontic treatment to coincide with growth may be a considerable factor in the stability of the dentition, and studies agree that the use of orthopedic maxillary expansion should be cautiously applied past the age of 15 years for females and 17 years for males. ${ }^{28}$

The nasal width was correlated with maxillary width for both males and females, indicating the relationship between airway and maxillary width. ${ }^{5}$ More than $80 \%$ of the maxillary growth is completed at age 6 to 11 years, with a higher rate in females; excluding nasal width - with a higher rate in males, which is only $75 \%$ complete in females, ${ }^{5}$ justifying the greater increase in nasal width in females found in the present study. The significant maxillary width/nasal width ratio value shows transverse growth of the nasal cavity and control of maxillary constriction, which are important for dental and skeletal relationships and nasal airway increase. The arch width and arch depth are dependent on each other; ${ }^{29}$ thereby, the increase of the nasal floor close to the midpalatal suture in width after RME and the growth in the vertical direction with a higher rate in males ${ }^{5}$ - according to longitudinal studies of facial growth- could explain their nasal height increase.
The analysis between males and females at $T_{1}$ and $T_{2}$ is shown in Table 5, which compares the mean values of all variables. The only two significant variables were: nasal width $(p=0.027)$ and nasal width/maxillary width ratio $(p=0.019)$. Negative values in the nasal width/maxillary width ratio and the radiographic evaluation in frontal and occlusal norms confirm that the maxilla was laterally moved, creating a pyramidal shape with the fulcrum located near frontonasal suture and PNS, with a larger opening in the anterior maxillary base. ${ }^{8}$

Studies have shown the benefits of RME for the enlargement of the nasal cavity and improvement of nasal permeability through otorhinolaryngologist evaluation, radiographic examination, rhinomanometry, acoustic rhinometry, ${ }^{7,11,12,30-35}$ and subjective evaluation conducted among patients reporting improved breathing. ${ }^{6,17}$

Many studies have emphasized the ability of RME to produce lateral expansion of the nasal cavity and to decrease nasal resistance ${ }^{6,7}$. According to the present study results, the use of RME showed favorable results in the treatment of maxillary constriction and increased nasal cavity for both sexes; thereby, a possibility is offered that some potential may exist for a young patient to "outgrow" a breathing problem.

The Table 6 shows the effects of RME on the skeletal, dental and nasal structures at $\mathrm{T}_{1}$ and $\mathrm{T}_{2}$. The results show that both males and females were significantly favored $(p<0.01)$ by the transverse increase of the maxilla and nasal cavity. After statistical analysis and comparison of measurements in males and females, all linear variables were not significant. The transversal changes were not significantly different between sexes in the treatment of maxillary constriction with RME for a sample with a mean age of 9 years and 7 months.

As this was a short-term study, the alterations observed in the pretreatment and immediate posttreatment radiographs represent the effects produced by the expander. It is important to point out that the time interval between the first and the second radiograph in this study did not exceed three months, which minimizes growth as a variable in the interpretation of the results. Therefore, studies of facial growth had to be considered in the interpretation of the differences between sexes.

\section{CONCLUSION}

There was no evidence that maxillary constriction in growing subjects is in any way associated with sex. 
The treatment of maxillary constriction with RME in mouth-breathing patients without nasal obstruction showed significant improvement in the nasal width/maxillary width ratio, representing a transverse increase of the nasal cavity.

\section{Author contributions}

Conception or design of the study: MCJ. Data acquisition, analysis or interpretation: MCJ, LHYN. Writing the article: MCJ, LHYN. Critical revision of the article: MCJ, LHYN, SSNP, RRF. Final approval of the article: MCJ, LHYN, RMG, AKY, SSNP, RRF.

\section{REFERENCES}

1. Magnusson A, Bjerklin K, Nilsson P, Jönsson F, Marcusson A. Nasal cavity size, airway resistance, and subjective sensation after surgically assisted rapid maxillary expansion: a prospective longitudinal study. Am J Orthod Dentofacial Orthop. 2011 Nov;140(5):641-51.

2. El H, Palomo JM. Airway volume for different dentofacial skeletal patterns. Am J Orthod Dentofacial Orthop. 2011 June;139(6):e511-21.

3. Cappellette M Jr, Beaini TL. A tomografia computadorizada no diagnóstico e análise de pacientes submetidos a disjunção maxilar - revisão de literatura e apresentação de caso clínico. Sci Pract. 2014;7(27):134-40.

4. McNamara JA. Influence of respiratory pattern on craniofacial growth. Angle Orthod. 1981 Oct:51(4):269-300

5. Snodell SF, Nanda RS, Currier GF. A longitudinal cephalometric study of transverse and vertical craniofacial growth. Am J Orthod Dentofacial Orthop. 1993 Nov:104(5):471-83.

6. Ramires T, Maia RA, Barone JR. Alterações da cavidade nasal e do padrão respiratório após expansão maxilar. Rev Bras Otorrilaringol. 2008;74(5):763-9

7. De Felippe NLO, Bhushan N, Silveira AC, Viana G, Smith B. Long-term effects of orthodontic therapy on the maxillary dental arch and nasal cavity. Am J Orthod Dentofacial Orthop. 2009 Oct;136(4):490.e1-8; discussion 490-1.

8. Haas AJ. Rapid expansion of the maxillary dental arch and nasal cavity by opening the midpalatal suture. Angle Orthod. 1961;31(2):73-90.

9. Haas AJ. Palatal expansion: just the beginning of dentofacial orthopedics Am J Orthod. 1970 Mar:57(3):219-55.

10. Basciftci FA, Mutlu N, Karaman Al, Malkoc S, Küçükkolbasi H. Does the timing and method of rapid maxillary expansion have an effect on the changes in nasal dimensions? Angle Orthod. 2002;72(2):118-23.

11. Kiliç N, Oktay $\mathrm{H}$. Effects of rapid maxillary expansion on nasal breathing and some naso-respiratory and breathing problems in growing children A literature review. Int J Pediatr Otorhinolaryngol. 2008 Nov;72(11):1595-601.

12. Palaisa J, Ngan P, Martin C, Razmus T. Use of conventional tomography to evaluate changes in the nasal cavity with rapid palatal expansion. Am J Orthod Dentofacial Orthop. 2007:132(4):458-66.

13. Lamparski DG Jr, Rinchuse DJ, Close JM, Sciote JJ. Comparison of skeletal and dental changes between 2-point and 4-point rapid palatal expanders Am J Orthod Dentofacial Orthop. 2003 Mar:123(3):321-8.

14. Ciambotti C, Ngan P, Durkee M, Kohli K, Kim H. A comparison of dental and dentoalveolar changes between rapid palatal expansion and nickel-titanium palatal expansion appliances. Am J Orthod Dentofacial Orthop. 2001 Jan:119(1):11-20

15. Cross DL, McDonald JP. Effect of rapid maxillary expansion on skeletal, dental and nasal structures: a postero-anterior cephalometric study. Eur J Orthod. 2000 Oct;22(5):519-28.

16. Cameron CG, Franchi L, Baccetti T, MCNamara JA Jr. Long-term effects of rapid maxillary expansion: a posteroanterior cephalometric evaluation. Am J Orthod Dentofacial Orthop. 2002 Feb;121(2):129-35; quiz 193.

17. Izuka EN, Feres MFN, Pignatari SSN. Immediate impact of rapid maxillary expansion on upper airway dimensions and on the quality of life of mouth breathers. Dental Press J Orthod. 2015 May-June;20(3):43-9.

18. Ricketts RM, Roth RH, Chaconas SJ, Schulhof RJ, Engel GA. Orthodontic diagnosis and planning. Denver: Rocky Mountain Data Systems; 1982.

19. Cohen J. A power primer. Psycol Bull. 1992;112(1):155-9
20. Faul F, Erdfelder E, Lang AG, Buchner A. G*Power 3: A flexible statistical power analysis program for the social, behavioral, and biomedical sciences. Behav Res Methods. 2007 May; 39(2):175-91.

21. Habeeb M, Boucher N, Chung CH. Effects of rapid palatal expansion on the sagittal and vertical dimensions of the maxilla: a study on cephalograms derived from cone-beam computed tomography. Am J Orthod Dentofacial Orthop. 2013 Sept:144(3):398-403.

22. Phatouros A, Goonewardene MS. Morphologic changes of palate after rapid maxillary expansion: A 3-dimensional computed tomography evaluation Am J Orthod Dentofacial Orthop. 2008 July:134(1):117-24

23. Hassan B, van der Stelt P, Sanderink G. Accuracy of three-dimensional measurements obtained from cone beam computed tomography surface rendered images for cephalometric analysis: influence of patient scanning position. Eur J Orthod. 2009 Apr;31(2):129-34.

24. Wriedt S, Kunkel M, Zentner A, Wahlmann UW. Surgically assisted rapid palatal expansion. An acoustic rhinometric, morphometric and sonographic investigation. J Orofac Orthop. 2001 Mar:62(2):107-15.

25. Warren DW, Hershey HG, Turvey TA, Hinton VA, Hairfield WM. The nasal airway following maxillary expansion. Am J Orthod Dentofacial Orthop. 1987 Feb; 91(2):111-6.

26. Vig KW. Nasal obstruction and facial growth: the strength of evidence for clinical assumptions. Am J Orthod Dentofacial Orthop. 1998 June:113(6):603-11.

27. Cross DL, McDonald JP. Effect of rapid maxillary expansion on skeletal dental, and nasal structures: a postero-anterior cephalometric study. Eur J Orthod. 2000 Oct:22(5):519-28

28. Bishara SE, Staley RN. Maxillary expansion: clinical implications. Am J Orthod Dentofacial Orthop. 1987 Jan; 91(1):3-14

29. Lindsten R, Ogaard B, Larsson E, Bjerklin K. Transverse dental and dental arch depth dimensions in the mixed dentition in a skeletal sample from the 14th to the 19th century and Norwegian children and Norwegian Sami children of today. Angle Orthod. 2002 Oct;72(5):439-48.

30. Cappellette M Jr, Carlini D, Pignatari SSN, Cruz OLM, Weckx LLM. Rinometria acústica em crianças submetidas à disjunção maxilar. Rev Dental Press Ortod Ortop Facial. 2006:11(2):84-92.

31. Muniz RFL, Cappellette M Jr, Carlini D. Alterações no volume nasal de pacientes submetidos a disjunção da maxila. Rev Dental Press Ortod Ortop Facial. 2008:13(1):54-9.

32. Cappellette M Jr. Disjunção maxilar. 1a ed. São Paulo: Ed. Santos; 2014 $432 \mathrm{p}$

33. Garrett BJ, Caruso JM, Rungcharassaeng K, Farrage JR, Kim JS, Taylor GD Skeletal effects to the maxilla after rapid maxillary expansion assessed with cone-beam computed tomography. Am J Orthod Dentofacial Orthop. 2008 July;134(1):8-9

34. Enoki C, Valera FC, Lessa FC, Elias AM, Matsumoto MA, Anselmo-Lima WT. Effect of rapid maxillary expansion on the dimension of the nasal cavity and on nasal air resistance. Int J Pediatr Otorhinolaryngol. 2006 July:70(7):1225-30.

35. Haralambidis A, Ari-Demirkaya A, Acar A, Küçükkeleş N, Ateş M, Ozkaya S. Morphologic changes of the nasal cavity induced by rapid maxillary expansion: a study on 3-dimensional computed tomography models. Am J Orthod Dentofacial Orthop. 2009 Dec:136(6):815-21 